\title{
Using crossword puzzles to improve English Level One students' spelling skill
}

\section{El uso de crucigramas para mejorar la destreza de deletreo en los estudiantes de Primer Nivel de Inglés}

Angela Cecibel Moreno Novillo. ${ }^{1}$, Martha Lucia Lara Freire. ${ }^{2}$, Jazmina Ivonne Mena Mayorga. ${ }^{3} \&$ Ana Jazmina Vera de La Torre. ${ }^{4}$

Recibido: 10-01-2020 / Revisado: 25-02-2020 /Aceptado: 04-03-2020/ Publicado: 03-04-2020

\begin{abstract}
.
DOI: https://doi.org/10.33262/cienciadigital.v4i2.1194

This paper entitled Using Crossword Puzzles to improve English Level One students' spelling skill, aims to improve spelling skills through crossword puzzles implementation in Level A1 students at Escuela Superior Politécnica de Chimborazo. The research design was quasi-experimental in which two groups, the control and the experimental were involved. For data collection, a 20 item questionnaire were designed and administered on 60 students belonging to the English Center at ESPOCH. The questionnaire was used for data collection. The research had a qualitative-quantitative approach conducted to analyze the problem, demonstrate the relation between variables, simplify and regulate the results gathered from the sample as well as the studied groups. In addition, a pre-test and a post-test were given to student to measure the effectiveness of the crossword puzzles implementation in the acquisition of the English spelling skill and data were tabulated by applying the software SPSS (Statistical Package for Social Sciences). The students' answers to the questionnaire showed that the attitude towards spelling skill and using of crossword puzzles was extremely positive. Therefore, the study concludes that the use of
\end{abstract}

1 Escuela Superior Politécnica de Chimborazo, Facultad de Mecánica. Riobamba, Ecuador, angela.moreno@espoch.edu.ec

2 Escuela Superior Politécnica de Chimborazo, Facultad de Salud Pública. Riobamba, Ecuador, mlaraf@espoch.edu.ec

3 Escuela Superior Politécnica de Chimborazo, Facultad de Mecánica. Riobamba, Ecuador, jazmina.mena@espoch.edu.ec

${ }^{4}$ Universidad Técnica de Ambato, Facultad de Ciencia de la Educación, Ambato, Ecuador. aj.vera@uta.edu.ec 
crosswords was one of the most effective ways for helping students to develop, improve and consolidate their spelling skill as well as being motivated to learn.

Keywords: Spelling skills, Crossword Puzzles, Research design, Quasiexperimental research.

\section{Resumen.}

El artículo titulado Uso de crucigramas para mejorar la habilidad de deletreo de los estudiantes del Nivel Uno de inglés, tiene como objetivo mejorar las habilidades de deletreo mediante la implementación de crucigramas en los estudiantes del Nivel A1 de la Escuela Superior Política de Chimborazo. El diseño de la investigación fue cuasi experimental en el que participaron dos grupos, el de control y el experimental. Para la recopilación de datos, se diseñó y administró un cuestionario de 20 ítems a 60 estudiantes pertenecientes al Centro de Idiomas de la ESPOCH. El instrumento utilizado para recopilar datos de investigación fue el cuestionario. La investigación tuvo un enfoque cualitativo-cuantitativo, mismo que permitió analizar el problema, demostrar la relación entre variables, simplificar y regular los resultados obtenidos de la muestra, así como los grupos estudiados. Adicionalmente, una prueba previa y una prueba posterior fueron aplicadas para medir la efectividad de la implementación de crucigramas en la adquisición de la habilidad de deletreo en inglés y los datos fueron tabulados mediante la aplicación del paquete estadístico SPSS (Statistical Package for Social Sciences). Las respuestas de los estudiantes al cuestionario mostraron que la actitud hacia la destreza de ortografía y el uso de crucigramas fue extremadamente positiva. Por lo tanto, el estudio concluye que el uso de crucigramas fue una de las formas más efectivas para ayudar a los estudiantes a desarrollar, mejorar y consolidar sus habilidades de ortografía, además de estar motivados para aprender.

Palabras claves: Habilidad de ortografía, Crucigramas, Diseño de Investigación, Investigación Cuasi-experimental.

\section{Introduction}

"Good English, well-spoken and well written will open more doors than a college degree" William Raspberry (Milne, Az Quotes, 2018). A professional who is able not only to interact in this language, but also write well-organized reports, essays, letters, and academic papers, will have more job opportunities and possibilities to be a successful person.

"Studies revealed that of the 4,000 to 5,000 living languages, English is most widely used, and it covers one-sixth of the world's population" (Broughton \& Brumfit, 2003). "In 
Ecuador, the Ministry of Education launched a new National English Curriculum with the purpose of removing inequality in access to English language learning in the public and private sectors and improve the quality of education at all levels" (British English, 2015).

The Ecuadorian education system regarding the teaching of the English language has been different from other education systems in Eastern countries whose laws and policies are not clear and have not shown much progress yet. In Ecuador, the teaching of English as a Foreign Language is focused on the language acquisition, development, and fluency, as well as in culture, curriculum development, assessment, professionalism, and ethical commitment in the classroom. (Garzón, 2018)

Then, considering the importance of mastering a second language, the present study focuses on spelling, one of the most important skills to develop the necessary ability to read and write fluently. At the same time, crossword puzzles implementation is proposed to give students the possibility to improve the spelling skill though an innovative and entertaining technique.

Since improving the spelling skills is one of the English language learning objectives, there have already been several researches on this area, some of the most relevant are mentioned below.

The first study entitled "The use of crossword puzzles to improve students' spelling" focused on finding out the effectiveness of crossword puzzles to improve the students' spelling in Elementary School students in Indonesia. The researcher concluded that after the intervention and as shown in the pre-test and post-test results the students' achievement in learning English spelling through crossword puzzles had a significant improvement, the grades improved in a 40\%. (Diniyati, 2009)

The second study was part of the 5th Congress on Applied Research in Languages studies held in Iran. The aim of the study was to investigate the impact of applying crossword puzzles on improving spelling among Iranian intermediate English as a Foreign Language male and female learners. The findings of the study demonstrated that crossword puzzles lead to increase motivation and interest concerning the selected topic to be taught, it was also proved that the use of crossword puzzles boosted learners' self-confidence in their ability, helped them in comprehending some of the concepts and motivated them to think about what they were learning. (Amiri \& Salehi, 2017)

Finally, in the scientific paper named "What research has to say about spelling instruction for English language learners" the author presents intellectual dialogues on prominent issues on spelling with English Language Learners and its effective instruction. The discussion presented in this research enriches the notion of L2 spelling, which revolves around crosslinguistic transfer, L2 literacy skills predictive of better spelling, and effective spelling instruction. At the end of this literature review the researcher concluded that the role that the 
L1 plays into the L2 must be considered, since L1 would contribute to L2 development or interfere L2 ability. Another aspect to take into consideration is the importance of phonological awareness, letter knowledge and orthographic knowledge as literacy components that contribute to spelling development. (Parlindungan, 2018)

The three studies mentioned above confirm the significance of teaching spelling to English as a Foreign Language students, and also demonstrated the efficiency of implementing crossword puzzles to improve this skill.

\section{Literature Review}

\section{Crossword Puzzles}

\section{Definition}

The crossword puzzle is a kind of word game where the player has to accurately fill in all the blank squares with letters that form words; these words are based on clues provided, which can be complete sentences, phrases, or words. Due to their learner-friendly characteristic, crossword puzzles help students extend their vocabulary knowledge and improve their spelling skills since they need to spell items correctly to complete the puzzle, which motivates them to learn new words and gain greater retention and memorization of vocabulary. (Orawiwatnakul, 2013)

\section{Benefits of crossword puzzles}

Crossword puzzles are not only an extremely entertaining game, but also a highly beneficial tool for both our mental and physical health. Some of the benefits of crossword puzzles are the following:

1. Enhances vocabulary. - considering that the foundation of any language is words, it is predominant to find a dynamic strategy for students to improve their English vocabulary; thus, crossword puzzles play an important role in this process. While reading and putting words together, students are developing a mental exercise, which indirectly enhances their verbal skills, and is going to be reflected on their communication skills.

2. Releases stress.- solving crossword puzzles is like meditating, the only goal is to complete it, and doing so, students quiet the noises, concentrate, and at the end they can enjoy a feeling of accomplishment.

3. Maintains social bonds.- besides being the best pass time activity, crossword puzzles strengthen social interaction since all the class shares the same goal and can support each other until crossword puzzle is solved.

4. Improves mental health.- the brain keeps working which means the cells are continuously activated; even more, crossword puzzle activities also develop the ability to think creatively and enhances analytical and cognitive skills. (Bhgat, 2018) 
5. Olivier (2017), mentions in her blog that "the first and most effective benefit of crossword puzzles is spelling practice and improvement since this tool requires students to spell words correctly to complete it" (Olivier, 2017).

\section{Spelling}

\section{Definition}

"Spelling is the student's ability to write a word accurately and the way in which a word is spelled; one of the strategies to teach spelling is the use of games, one of which is crossword puzzles" (Amiri \& Salehi, Impacts of applying crossword puzzles on improving spelling, 2017).

Spelling is the art of correctly assembling words from their letters and it is one of the essential components of successful writing. When a student develops the ability to recognize links between words of the same origin and word relationships that means they are improving their communication skills. Teaching students, strategies, rules, and concepts to grow their spelling and vocabulary knowledge, benefits them in all aspects of their learning, as well as in their everyday life. Since learners who feel confident with letters and word patterns are able to read and comprehend more complex texts and they also have the necessary language tools to better convey their own ideas through both written and verbal communication. (Reed, 2012)

\section{Approaches to spelling instruction}

Spelling instruction used to be taught as a specific lesson on the timetable, teachers provided students with weekly spelling fists, based on the new vocabulary from various topics or word families which were studied during a class. The main focus was for students to know the meaning of the words and use them appropriately in sentences; then, a test was administrated to ensure that the words had been memorized correctly. Nevertheless, there was a deficiency, students memorized words from lists, but did not spell them correctly in writing activities.

During the late 1970s and 1980s significant shifts occurred in the general approach to literacy teaching; there was a movement away from skill-based instruction to a more holistic and integrated approach to reading, writing, and spelling. In this approach, spelling deals with context in daily writing since studying words in isolation does not help the student to transfer and use this knowledge when writing. (Westwood, 2004)

Finding innovative approaches, strategies, and techniques has been one of the core tasks for teachers of English as a Foreign Language; for that reason, this study presents an effective and entertaining tool which is crossword puzzles.

\section{Objectives}

\section{General Objective}

- To implement crossword puzzles activities to improve students' spelling skill in Level A1 students. 


\section{Specific Objectives}

- To identify the spelling skill level in A1 level English students.

- To develop crossword puzzles activities in the English as a Foreign Language classroom for spelling skill improvement.

- To measure the effectiveness of crossword puzzles activities in the spelling skill improvement in A1 level students.

\section{Methodology}

The methodology includes the following parameters such as the research participants, the instruments and the procedure. The present research corresponds to a quasi-experimental design which was used to establish the effect of the independent variable on the dependent variable. On the one hand, the experimental and control groups were not chosen at random, these groups were assigned before the experiment. On the other hand, randomization helped the researcher to make sure that there is no pre-existing condition that influences the variables and destroys the results. This quasi-experimental research was carried out in an educational setting. During the research, the data were obtained through pre-test and post-tests. As a consequence, pretest and posttest data improved student performance in spelling. Finally, the results obtained during the intervention were analyzed and compared. (Rogers, 2019).

\section{Research participants}

The participants of this study were 60 university male and female English as a Foreign Language learners from Escuela Superior Politécnica de Chimborazo. Their age ranged was from 18 to 20 years old. The participants were assigned to two different groups experimental and control, 30 learners in each.

\section{Research instruments}

The instrument used for data collecting was a questionnaire focused on spelling questions. These questions were based on misspelling, matching and taking notes. In addition, the technique administered to the participants in the study was pre-test and post-test. In order to tabulate and compare results, an Excel spreadsheet was used. In addition, the crossword puzzles were designed using Microsoft Word, and the topics were chosen from the syllabus of Escuela Superior Politécnica de Chimborazo.

\section{Procedure}

The setting of this study was two English classrooms of Escuela Superior Politécnica de Chimborazo located in Riobamba, Ecuador. The experimental group crossword puzzles according to the syllabus topics and the control group teacher applied traditional methods to teach the same word list. After selecting the sample, the pre-test was administered in the first session of the learning period for being aware of the student's performance in the spelling 
test before the intervention which had a length of two months. At the end of this period, the post-test was administered to identify the spelling improvement in first level university students.

\section{Population and sample}

The researcher selected level one since the students are beginners and do not have the necessary knowledge. For this reason, it is considered important to provide more opportunities to produce the correct spelling representation of a written word.

In order to calculate the sample size, the following formula was applied:

$n=N \sigma 2 Z 2(N-1) e 2+\sigma 2 Z 2$

Where:

$\mathrm{n}=$ sample size

$\mathrm{N}=$ population size

$\sigma=$ population standard deviation, generally when there is not value, the constant value 0,5 is used.

$\mathrm{Z}=$ obtained value through reliability levels. It is a constant value, if there is no value, the relation of reliability $95 \%$ is taken which is equivalent to 1,96 (as more common)in a relation to $99 \%$ of 2,58 of equivalent reliability, this value is chosen according to the research criterion.

$\mathrm{e}=$ acceptable limit of sample error, which generally if it does not have a value, the used value is from $1 \%(0,01)$ and $9 \%(0,09)$.

Formula:

$\mathrm{N}=71 n=71(0,5) 2(1,96) 2(71-1)(0,05) 2+(0,5) 2(1,96) 2 n=68,18841,1354 n=60$

Once applied the formula, the sample were two groups of 30 students (Urquizo, 2005).

\section{Results}

The analysis of the present research was carried out to the total population of the students since the study universe was small, so it does not limit the application of the pre-test and post-test to the 60 students who are in first English level at Escuela Superior Politécnica de Chimborazo.

For the application of the pre-test and post-test, there was a brief explanation of each question by the researcher to the participants, so that there was no confusion when answering certain questions, the same ones that were of great help when designing the proposal.

Taking into account the above mentioned and through the tabulation of data, quantitative results were obtained, which were analyzed and interpreted in order to validate the research proposals and make possible their application as new teaching tools or techniques. 
Once the data have been collected, the researcher analyzed the results obtaining from the pretest and post-test of the experimental and control groups. The statistical calculation of the experimental group and the control group were as follows:

\section{EXPERIMENTAL GROUP DATA INTERPRETATION}

Graph 1. Experimental Group Spelling Scores

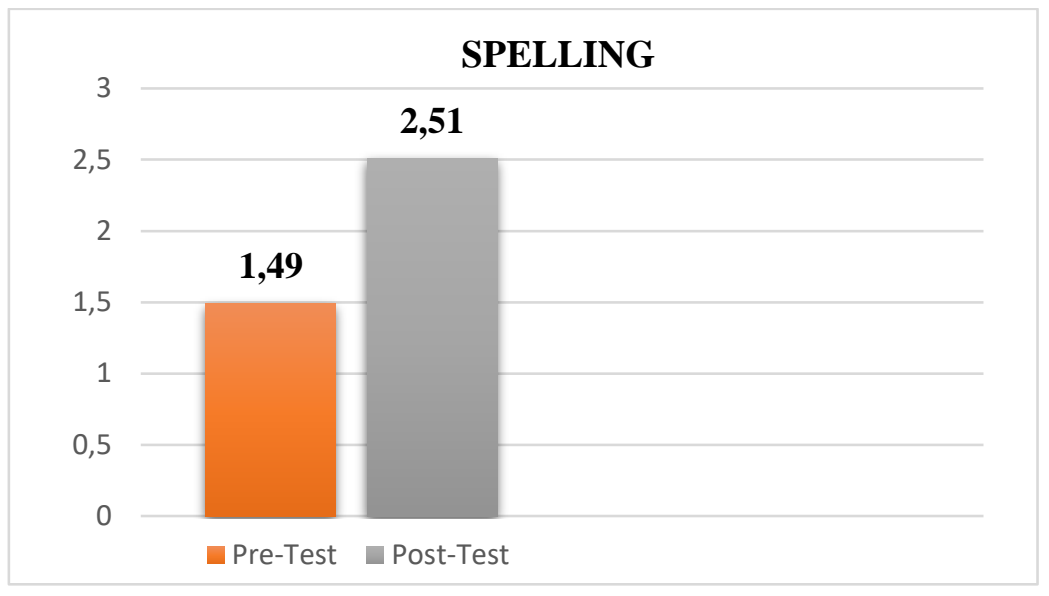

Source: Experimental Group Pre-Test and Post-Test

Author: Cecibel Moreno

\section{Analysis and interpretation}

In regard to the experimental group spelling scores, as shown in graph 1, the average in the pre-test was $1,49 / 3$. This means that students who face problems to spell do not produce the close approximations of target words necessary for the spell checker to suggest the correct word. Thus, Monson stated that "a basic spelling vocabulary of 2,800 to 3,000 well-selected words should form the core for spelling instruction” (Monson, 1979, pág. 20).

However, the post-test students' scores improved and increased to 2,51/3, which means there is a difference of 1,02 . In this study that difference was pivotal since during the time of the intervention the researcher implemented crossword puzzles activities with the purpose of improving students spelling skill. The activities involved combining several useful skills including reasoning, spelling, and vocabulary.

Spelling is a vital part of the educational process; for that reason, this dimension was considered for the current research in order to give students the possibility not only to learn more words but also to provide a big boost in learning their pronunciation and meaning. Furthermore, spelling instruction is crucial. In short, spelling instruction sensitizes students 
to the underlying structure of words and is one of the means by which they begin to acquire fluency in academic language (Jones, 2009).

\section{Control Group Data Interpretation}

Graph 2. Control Group Spelling Scores

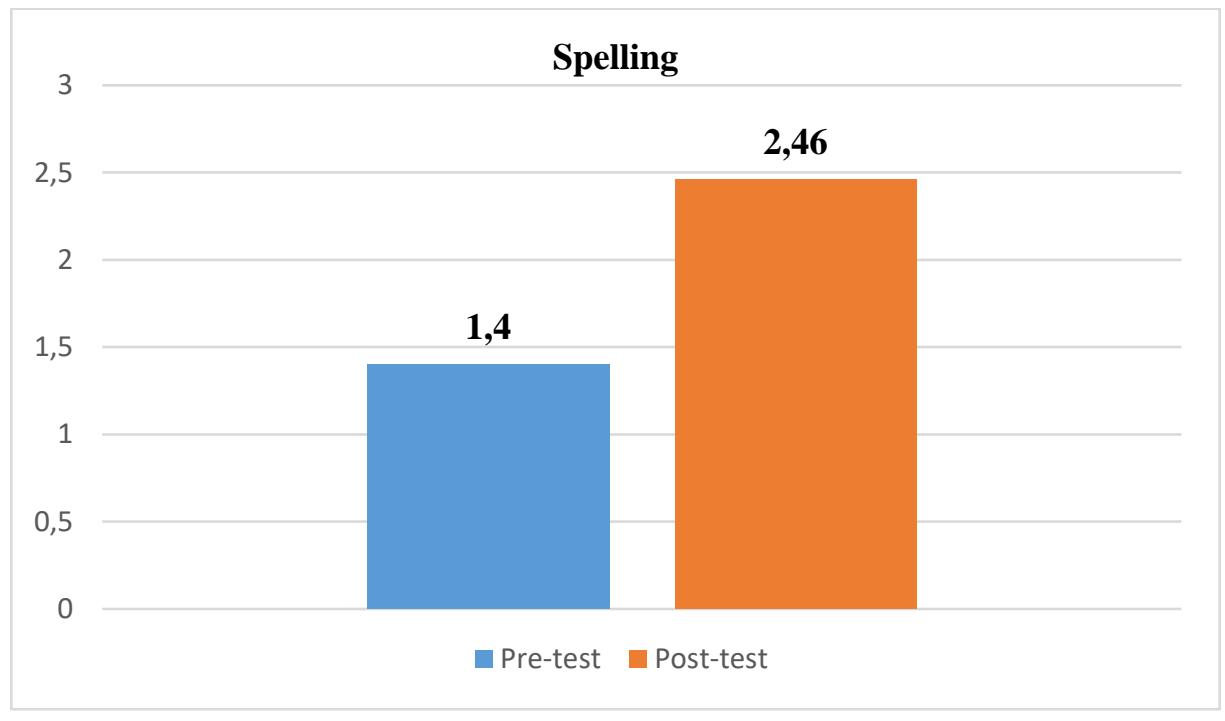

Source: Experimental Group Pre-Test and Post-Test

Author: Cecibel Moreno

\section{Analysis and interpretation}

Graph 2 divulges the fact that the average students from the control group got in the pre-test was $1,40 / 3$. It is necessary to emphasize that all questions were focused on single words, compound words, and word patterns. However, there are some mistakes that students showed in the pre-test such as similarities in pronunciation with other words, mistakes in alphabet structure, wrong usage, or simply an oversight by the student. The students obtained 2,46/3 in the post-test. This means that, the advance was 1,06. These results showed that the control group improvement was 0,4 higher than the experimental group; nevertheless, the overall average of the experimental group spelling skill test is higher than the control group. This means that the traditional memorization strategies are as effective as the use of crossword puzzles (Moreno, 2019).

\section{Discussion}

The general findings of this research indicate that the use of crossword puzzles helps and inspires level A1 students to improve their vocabulary and spelling as well as increases classroom participation and creates a good atmosphere in the classroom. Hence, Njoroge 
(2013) states that the use of crossword puzzles was a dynamic strategy for teaching vocabulary in Kenyan classrooms helping students to improve their language skills. Furthermore, the use of crossword puzzles was stablished to help students enjoy and gain interest during their English class.(Njoroge, 2013).

Thus, improving spelling skills, gaining confidence in writing, becoming more confident and, therefore, achieving success in the learning process. Furthermore, spelling is an important skill in language learning, and it is considered as a central feature of reading and writing. To sum up, it is necessary to mention that spelling is crucial in communication and comprehension. This means that spelling facilitates communication by following the same rules for spelling words, as well as understand the text and read. In comprehension, a good spelling avoids confusion. For that reason, teachers should use crossword puzzles to teach spelling (Silliman \& Wilkinson, 2007).

It is worth mentioning that one of the techniques for teaching English is the use of crosswords that allows the student to build and improve their spelling. Moreover, according to Thornbury (2002), crossword puzzles help the students to be more familiar with the words, recognize the words, manipulate and remembering the words. Therefore, crossword puzzles are an engaging way to get students to practice their spelling and vocabulary words (Thornbury, 2002, págs. 27-28).

Hence, crossword puzzles are still a fantastic educational tool used to develop different skills such as verbal reasoning, vocabulary, problem-solving, spelling, grammar and memory. Further, McKeachie (2002) states that by solving the crossword puzzles, students achieve many benefits in learning English. For example, students understand and learn English words, successfully spell words, develop spelling skills, and acquire a high degree of interest in learning. (McKeachie, 2002).

In the study conducted by Diniyati (2009), the author states that one of the basic needs to gain a good achievement of the target language is the development of the spelling ability. Consequently, crossword puzzles provide multiple exposures and practice opportunities to spelling and vocabulary words which helps increase the likelihood of their retention (Diniyati, 2009).

In short, this research helped to improve first level students' spelling skill by using crossword puzzles as demonstrated on the average result of the post-test where the active participation of the students increased from $1.49 \%$ to $2.51 \%$, that is to say, there was an improvement of as much as $1.02 \%$. Finally, it can be concluded that crossword puzzles can help students improve their knowledge of vocabulary, spelling while also increasing their motivation to learn. 


\section{Conclusions}

The two-month period intervention, the tests results and analysis generated the following conclusions:

- Crossword puzzles activities were implemented during the intervention as a contribution for the spelling skill improvement in Level 1 students; some of which were adapted by the teacher and at the end of the intervention students were even able to create their own puzzles, not only to reinforce their knowledge, but also to actively contribute to the research objective. Besides, there was a combination between printed and online material related to each vocabulary topic; giving the students the possibility to use technology as well.

- The spelling skill level was diagnosed at the beginning of the intervention through a pre-test which included questions directed specifically to develop the spelling skill such as dictation, word matching and crossword puzzles completion, and the average was $1,49 / 2$.

- The effectiveness of crossword puzzles was measured based on the post-test application; once the intervention finished, the students took the test and the average was 2,51/2, 1,02 points over the pre-test score.

- Then, crossword puzzle use in the English as a Foreign Language classroom contributes significatively to students spelling skill improvement while motivating them to actively participate in their learning process though innovative and fun activities.

\section{Bibliography}

Amiri, B., \& Salehi, H. (2017). Impacts of applying crossword puzzles on improving spelling. Language Studies.

Amiri, B., \& Salehi, H. (2017). Impacts of Applying Crossword Puzzles on Improving Spelling Among Iranian Intermediate EFL male and female learners. Applied Research on Language Studies.

Bhgat, N. (2 de Febrero de 2018). Wealth Words. Obtenido de https://www.wealthwords.com/blog/the-benefits-and-advantages-of-playingcrossword-puzzles/

British English. (2015). Obtenido de https://www.teachingenglish.org.uk/sites/teacheng/files/English\%20in\%20Ecuador. pdf 
Broughton, G., \& Brumfit, C. (2003). Teaching English as a Foreign Language. New York: Routledge \& Kegan Paul Ltd.

Diniyati, N. (2009). The use of crossword puzzles to improve students' spelling . Semarang: UNNES.

Garzón, J. (2018). English Foreign Language in Ecuador. ResearchGate.

Jones, S. (2009). Vocabulary Spelling City. Obtenido de https://www.spellingcity.com/importance-of-spelling.html

McKeachie. (2002). Teaching Tips. Boston: Houghton Mifflinn Co., c2002.

Milne, A. (2018). Az Quotes. Obtenido de https://www.azquotes.com/quotes/topics/spelling.html

Monson. (1979). Focus on exceptional children.

Moreno, C. (2019). Crossword puzzles and the acquisition of university students' vocabulary. Ambato: Universidad Tècnica de Ambato.

Njorage, N. G. (2013). The Use of Crossword Puzzles as a Vocabulary Learning Strategy: A Case of English as a Second Language in Kenyan Secondary Schools. Kenyan: International Journal of Current Research.

Olivier, K. (2017). WorksheetCloud. Obtenido de https://www.worksheetcloud.com/blog/9reasons-your-child-should-do-word-puzzles-every-day/

Orawiwatnakul, W. (2013). El uso de crucigramas como herramienta en el desarrollo de vocabulario. Electronic Journal of Research in Educational Psychlogy , 413-428.

Parlindungan, F. (2018). What research has to say about spelling instruction for English language learners. ResearchGate.

Reed, D. (2012). Why teach spelling? El Paso: Center on instruction.

Rogers, J. (2019). Experimental and quasi-experimental designs. Reasearch Gate.

Silliman, E., \& Wilkinson, L. (2007). Language and Literacy Learning in Schools. New York: The Guilford Press.

Thornbury, S. (2002). How to teach vocabulary. Harlow: Pearson.

Westwood, P. (2004). Spelling approaches to teaching and assessment. New York: British Library. 


\section{PARA CITAR EL ARTÍCULO INDEXADO.}

Moreno Novillo, A. C., Lara Freire, M. L., Mena Mayorga, J. I., \& Vera de La Torre, A. J. (2020). Using crossword puzzles to improve English Level One students' spelling skill. Ciencia Digital, 4(2), 19-31. https://doi.org/10.33262/cienciadigital.v4i2.1194

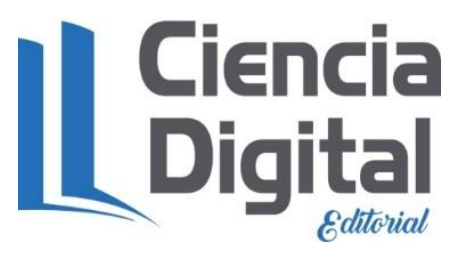

El artículo que se publica es de exclusiva responsabilidad de los autores y no necesariamente reflejan el pensamiento de la Revista Ciencia Digital.

El artículo queda en propiedad de la revista y, por tanto, su publicación parcial y/o total en otro medio tiene que ser autorizado por el director de la Revista Ciencia Digital.
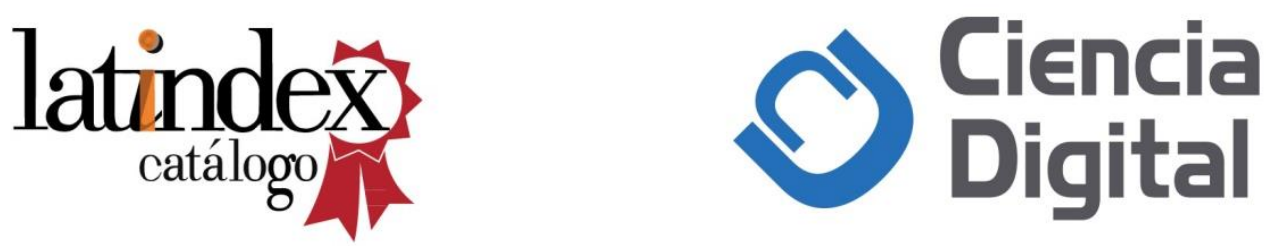